\title{
THE POSTURAL STATUS OF SPINAL COLUMN OF SEDENTARY MUSIC HIGH SCHOOL STUDENTS IN NIS, SERBIA
}

\section{POSTURÁLNÍ STAV PÁTEŘE U SEDÍCíCH HUDEBNÍKŮ NA STŘEDNÍ HUDEBNÍ ŠKOLE - NIŠ, SRBSKO}

\author{
Tijana Purenovic* \\ Faculty of Sport and Physical Education, University of Niš, Serbia
}

\begin{abstract}
The research was carried out with the aim of determining the postural status of spinal column of sedentary female and male pupils - musicians of fiddle, brass, piano and singing department of Music High School in Nis. The sample of examinees consisted of 68 sedentary pupils - musicians ( 36 female and 32 male pupils) aged 15 to 19. The postural status of spinal column was estimated according to three variables (lordotic, kyphotic and scoliotic bad body posture), and it was established by the method of somatoscopy and somatometry. The influence of the way of carrying an instrument suitcase was estimated by the questionnaire. The results of the research have shown that every of these 68 sedentary pupils musicians has at least one of these three postural deformities. Also, t-test has shown that statistically, there is a significant difference between the pupils of fiddle department and the pupils of other departments, and between female and male pupils as well.
\end{abstract}

Key words: postural deformities, female, male, musicians, instrument suitcase carrying type

\section{SOUHRN}

Cílem výzkumné studie zjistit stav držení těla v oblasti páteře u studentek a a studentů střední hudební školy v Niši, hrajících v sedě na smyčcové a žest'ové nástroje , piano a členy pěveckého. Výzkumný soubor tvořilo 68 sedících žáků - hudebníků (36 ženského a 32 mužského pohlaví ) ve věku od 15 -ti do 19-ti let. Držení těla v oblasti páteře bylo zjištováno ve třech proměnných - odchylky lordotické, kyfotické a skoliozní, pomocí somatoscopických a somatometrických metod. Dále byl použit dotazník k získání údajů o způsobu nošení nástroje. Výsledky ukázaly, že všech 68 zkoumaných osob mělo přinejmenším jednu ze tří zkoumaných diferencí v držení těla. Statisticky významné rozdíly byly prokázány mezi houslisty a dalšími hudebníky, rovněž tak mezi oběma pohlavími.

Klíčová slova: poruchy v držení těla, ženské a mužské pohlaví, způsob nesení hudebního nástroje

School as an educational institution represents one of the important factors in versatile formation and development of young people and their personalities. However, by some of its influences such as long sitting in school desks no adequate to the chronological age (Smodlaka et al., 1955; according to Milenkovic, 2001), irregular backpack carrying (Nola, 1981; according to Zivkovic, 1987; Bogdanovic, 2005), school can exert adverse effects on psychosomatic development of children. As a consequence of these and other negative factors school age children can develop irregular body posture.

\footnotetext{
* The author is a postgraduate student of Faculty of Sport and Physical Education, University of Nis, and a Ministry of Science - Serbia stipend, engaged in the research project The Culture of peace,Identities and Interethnic relationships in Serbia and in the Balkans in the Eurointegration Process (149014D), which is being carried out at the Institute of Sociology of the Faculty of Phylosophy, University of Nis.

Autorka je studentkou postgraduálního studia na fakultě tělesné výchovy a sportu na Universite Niš a získala ministerské stipendium v rámci výzkumného projektu Mírová kultura, identita a polyetnické prostredí v Srbsku a na Balkáně v procesu evropské integrace (14901D), jehož řešitelem je Sociologický institut filosofické fakulty na Universitě Niš.
} 
In Music High School in Nis, physical education curriculum envisages one class per week and it is very badly attended by the above mentioned high school students. Therefore, students encompassed by this research are sedentary persons, physically inactive, that have for some short time in their lives taken up some kind of sport, or have never before taken any sport actively at all. Besides, one should take into account that the obligation of these students is every day long hours practicing, i.e. playing some instrument (brass or string one), whereby it is inevitable to assume some kind of irregular body position (asymmetric, seen in sagital and frontal plane). One of these essential exogenic factors of high school students' regular body posture marring is the way they carry their instrument suitcase.

Therefore, the research problem is to determ the postural status of the spinal column of different music department's students, and to survey the influence of the way of instrument suitcase carrying on their postural status. For the estimation of the postural status of the spinal column following variables were used: lordotic, kyphotic and scoliotic bad body posture.

\section{Method}

\section{Subjects}

This research has encompassed 68 Music High School students in Nis, instrumentalists, aged 1519. The whole sample was divided into sub-samples such as: fiddle profile -15 subjects, brass profile-14 subjects, piano players - 32 subjects, and singers profile -7 subjects.

\section{Measures and Procedures}

For the estimation of postural deformities of the spinal column there was used a somatoscopy and somatometric method (Zivkovic, 2000), and for the measurements we used plumb line, millimetre ruler, and dermograph-pencil.

The influence of long playing of brass or fiddle instruments and the carrying type of instrument suitcase, as important exogenic factors that deteriorate regular body posture, was estimated by survey questionnaire filled in by the subjects.

All the analyses were carried out by the statistical package for data processing STATISTICA 6.0. For each applied variable basic parameters of descriptive statistics (average value, standard deviation, coefficient of variation, minimum and maximum value, Range, skewness, kurtosis) were calculated and statistical significance of differences was determined by means of t-test.

\section{Results}

Out of 68 subjects, $46(67.6 \%)$ have a lordotic bad body posture, 29 (42.6\%) were found to have kyphotic bad body posture, while 57 (83.8\%) of them have a deformity of spinal column in frontal plane. It can be noticed that most percentage of the subjects $(83.8 \%)$ have a scoliotic bad body posture, somewhat smaller number of subjects $(67.6 \%)$ have lordotic bad body posture, whereas the smallest percentage of kyphotic bad body posture is detected $(42.6 \%)$.

Out of total $68,17(25 \%)$ have one of the measured postural deformities of the spinal column, $37(54.4 \%)$ have two out of these three postural deformities, and in $14(20.6 \%)$ subjects all three postural deformities were detected.

Out of 15 fiddle profile sample, lordotic bad body posture was detected in seven $(46.6 \%)$ subjects, kyphotic bad body posture in eight (53.3\%), while scoliotic bad body posture was most often represented and found in $12(80 \%)$ this profile students. These results (the most frequent scoliotic bad body posture) were expected ones if one takes into account that playing fiddle instruments implies that player's body is in asymmetric position viewed from the frontal plane.

Even in brass profile students the most frequent position is scoliotic bad body posture. Out of 14 subjects, $13(92.9 \%)$ have this kind of deformity, 12 $(85.7 \%)$ have lordotic bad body posture, while the least noticed is kyphotic bad body posture (four students, i.e. $28.6 \%$ ).

When talking about piano profile students, they play instruments in sedentary position that can in turn cause the changes on the spinal column in sagital plane. However, our measurements have shown some other results. Namely, out of 32 subjects $27(84.4 \%)$ have a deviation of spinal column in frontal plane, smaller number of students (21, i.e., 65.6\%) have lordotic bad body posture, and the least represented is a kyphotic bad body posture (14 students, i.e. $43.8 \%$ ).

In singer profile students, that during the singing classes have to mind their adequate body posture (because of a correct singing technique), have also manifested all three types of mentioned spinal column deviations. Out of seven students, six of them (85.7\%) have shown lordotic bad body posture, five students $(71.4 \%)$ have scoliotic bad body posture, and three $(42.9 \%)$ have shown kyphotic bad body posture. Thus singer profile students, due to long hours standing and weak abdomen and back muscles, have developed increased lumbal curve and deformed spinal column in the sagital plane.

Out of 68 students encompassed by this research, $29(42.7 \%)$ (fiddle and brass profile students) carry their instrument suitcase hanged on one shoulder, 20 students, i.e. $69 \%$, in a hand, and on both shoulders 9 students, i.e. $31 \%$. 
Table 1. Carrying type of instrument suitcase

Tabulka 1. Způsoby nošení hudebního nástroje

\begin{tabular}{|l|c|c|c|c|}
\hline \multirow{2}{*}{ I carry suitcase: } & \multicolumn{2}{c|}{ Fiddle profile students } & \multicolumn{2}{c|}{$\begin{array}{c}\text { Brass profile } \\
\text { students } \\
(\mathrm{N}=14)\end{array}$} \\
& \multicolumn{2}{|c|}{$(\mathrm{N}=15)$} & $\mathrm{N}$ & $\%$ \\
\cline { 2 - 5 } & $\mathrm{N}$ & 46.6 & 4 & 28.6 \\
\hline 1. On one shoulder & 7 & 26.6 & 5 & 35.7 \\
\hline 2. In one hand & 4 & 26.6 & 5 & 35.7 \\
\hline 3. On both shoulders & 4 & & & \\
\hline
\end{tabular}

By analysing Table 1 we can see that most number of fiddle profile students belong to the group of one shoulder suitcase carrying type $(46.6 \%)$, while same number of students carry their suitcases in one hand, i.e. on both shoulders (26.6\%). When talking about brass profile students, greater number of them decides to carry their suitcases in one hand, i.e. on both shoulders $(35.7 \%)$, and a smaller number of them carry the suitcase on one shoulder $(28.6 \%)$.

Table 2 shows presence of lordotic, kyphotic and scoliotic bad body posture of fiddle and brass profile students in regard to the instrument suitcase carrying type. It is evident that both profiles of students (fiddle and brass) carrying suitcase on one shoulder or in one hand manifest more scoliotic body posture. When we talk about subjects carrying suitcase on both shoulders, fiddle profile students manifest equally both kyphotic and scoliotic bad body posture, while brass profile students manifest more scoliotic bad body posture.

When analysing results shown in Table 3 it can be noticed that the average value is the highest for lordotic body posture variable $(9.46 \pm 9.29 \mathrm{~mm})$, and that it is the smallest for the kyphotic body posture variable $(3.91 \pm 5.57 \mathrm{~mm})$. Extremely high values of the variation coefficient point to the heterogeneity of the sample, and the biggest heterogeneity is manifest in kyphotic bad body posture variable $(\mathrm{Cv}=142.46 \%)$. Kurtosis values are smaller than 2.75 , which mean that the results are scattered.

Table 2. Presence of postural deformities in regard to instrument suitcase carrying type Table 2. Posturální deformity v závislosti na způsobu nošení hudebního nástroje

\begin{tabular}{|c|c|c|c|c|c|c|c|c|}
\hline \multirow{2}{*}{ I carry suitcase: } & \multicolumn{4}{|c|}{ Fiddle profile students $(\mathrm{N}=15)$} & \multicolumn{4}{|c|}{$\begin{array}{l}\text { Brass profile students } \\
\qquad(\mathrm{N}=14)\end{array}$} \\
\hline & $\mathrm{N}$ & LLD & KLD & SLD & $\mathrm{N}$ & LLD & KLD & SLD \\
\hline 1.On one shoulder & 7 & 1 & 4 & 5 & 4 & 1 & 2 & 4 \\
\hline 2 In one hand & 4 & 0 & 2 & 4 & 5 & 4 & 1 & 6 \\
\hline 3. On both shoulders & 4 & 2 & 3 & 3 & 5 & 2 & 3 & 4 \\
\hline
\end{tabular}

Legend: (LLD) - lordotic bad body posture; (KLD) - kyphotic bad body posture; (SLD) - scoliotic bad body posture); N number

Table 3. Basic descriptive parameters of the applied variables in all students-instrumentalists Tabulka 3. Parametry porměnných u všech studentů - hudebníků

\begin{tabular}{|c|c|c|c|c|c|c|c|c|c||}
\hline Var & N & Mean & SD & Cv\% & Min & Max & Range & Skew. & Kurt. \\
\hline \hline LLD & 68 & 9.46 & 9.29 & 98.20 & .00 & 35.00 & 35.00 & .73 & -.24 \\
\hline KLD & 68 & 3.91 & 5.57 & 142.46 & .00 & 24.00 & 24.00 & 1.50 & 1.82 \\
\hline \hline SLD & 68 & 7.63 & 7.29 & 95.54 & .00 & 28.00 & 28.00 & 1.02 & .37 \\
\hline
\end{tabular}

Legend: (LLD) - lordotic bad body posture; (KLD) - kyphotic bad body posture; (SLD) - scoliotic bad body posture; N number; Mean - average value; SD - standard deviation; $\mathrm{Cv}$ - coefficient of variation; Min - minimum value; Max maximum value; Skew. - skewness; Kurt. - kurtosis 
Table 4. Significance of the differences (t-test) between the fiddle profile students $(F)$ and other instrumentalists $(B-\mathbf{P}-\mathbf{S})$

Tabulka 4. Rozdíly mezi houslisty a ostatními hudebníky

\begin{tabular}{|c|c|c|c|c|c|c|c|c|c||}
\hline Var & $\begin{array}{c}\text { Mean } \\
\text { F }\end{array}$ & $\begin{array}{c}\text { Mean } \\
\text { B-P-S }\end{array}$ & $\begin{array}{c}\text { N } \\
\text { F }\end{array}$ & $\begin{array}{c}\text { N }-P-S \\
\text { SD }\end{array}$ & $\begin{array}{c}\text { SD } \\
\text { B-P-S }\end{array}$ & t-value & df & p \\
\hline LLD & 7.87 & 9.91 & 15 & 53 & 9.70 & 9.22 & -.75 & 66 & .457 \\
\hline KLD & 6.47 & 3.19 & 15 & 53 & 7.25 & 4.84 & 2.06 & 66 & $\mathbf{. 0 4 4}$ \\
\hline \hline SLD & 9.83 & 7.01 & 15 & 53 & 9.70 & 6.43 & 1.33 & 66 & .187 \\
\hline
\end{tabular}

Legend: (LLD) - lordotic bad body posture; (KLD) - kyphotic bad body posture; (SLD) - scoliotic bad body posture; Mean - average value; $\mathrm{N}$ - number; $\mathrm{SD}$ - standard deviation

Table 5. Significance of differences ( $t$-test) between the female $(Z)$ and male $(M)$ students instrumentalists

Tabulka 5. Významné rozdíly mezi hudebnicemi a hudebníky

\begin{tabular}{|c|c|c|c|c|c|c|c|c|c|}
\hline Var & $\begin{array}{c}\text { Mean } \\
\mathrm{Z}\end{array}$ & $\begin{array}{c}\text { Mean } \\
\text { M }\end{array}$ & $\begin{array}{l}\mathbf{N} \\
\mathbf{Z}\end{array}$ & $\begin{array}{l}\mathbf{N} \\
\mathbf{M}\end{array}$ & $\begin{array}{c}\text { SD } \\
\mathbf{Z}\end{array}$ & $\begin{array}{l}\text { SD } \\
\text { M }\end{array}$ & t-value & df & $\mathbf{p}$ \\
\hline LLD & 11.70 & 6.94 & 36 & 32 & 9.51 & 8.50 & 2.16 & 66 & .034 \\
\hline KLD & 2.25 & 5.78 & 36 & 32 & 4.07 & 6.45 & -2.73 & 66 & .008 \\
\hline SLD & 6.25 & 9.18 & 36 & 32 & 5.45 & 8.76 & -1.68 & 66 & .098 \\
\hline
\end{tabular}

Legend: (LLD) - lordotic bad body posture; (KLD) - kyphotic bad body posture; (SLD) - scoliotic bad body posture; Mean - average value; $\mathrm{N}$ - number; $\mathrm{SD}$ - standard deviation

Table 4 gives statistical significance of differences in arithmetic means of the tested variables between the fiddle profile students and all the other instrumentalists (brass, piano and singer profile students). Results show that between the fiddle profile students and students of other profiles there is a statistically significant difference in KLD variable, i.e. in fiddle profile students this postural deformity is of statistically more significant high values compared to the brass, piano and singer profile students.

By analysing the results in Table 5 one can conclude that even between the female and male students - instrumentalists there is a statistically significant difference in KLD variable and also in LLD variable. This means that in male students instrumentalist kyphotic bad body posture has significantly higher values in comparison to the female students - instrumentalists, and in female students - instrumentalist lordotic bad body posture has significantly higher values than in male students of Music High School in Nis.

\section{Discussion}

As in numerous previous researches it is confirmed that the school population of young, middle and higher school age is highly risky and susceptible to postural deformities and bodily disturbances (Jankovic, 1952; according to Zivkovic, 1987; Blazevic, 1971; according to Milenkovic, 2001; Nedvidek et al., 1975; according to Milenkovic, 2001; Zivkovic \& Milenkovic, 1993; Cywinska-Wasilewska, 1977; according to Zivkovic, 1987).

When we drew up subject, problem, aim and targets of this research we have set out from the assumption that long hours musical instrument playing (whether brass or fiddle) is possibly a risky factor of the bad body posture development and our measurements have this fact verified. Namely, in all students - instrumentalists encompassed by this research one or more types of postural deformities of spinal column have been identified. Surely one should take into account other risky factors such as instrument suitcase carrying in one hand or on one 
shoulder. Surveying of the subjects have shown that out of 20 students - instrumentalists, carrying their instrument suitcase on one shoulder or in one hand, 18 (90\%) have manifested scoliotic body posture, and out of nine students carrying their suitcases on both shoulders five $(55.5 \%)$ have kyphotic bad body posture.

One more significant factor taken into consideration is subjects' physical activity, that is their leisure time sporting activities. Survey has shown that out of 68 subjects, $38(55.9 \%)$ have taken some kind of sport and 30 students (44.1\%) have never played any sport. These data completely account for the fact that high percentage of students - instrumentalist of Music High School in Nis has displayed bad body posture.

On univariate level (t-test) between the fiddle and other profile students -instrumentalists and between female and male students instrumentalists, there are statistically significant differences in the following variables: kyphotic bad body posture (KLD) and scoliotic bad body posture (SLD), i.e. lordotic bad body posture (LLD).

\section{REFERENCES}

Bogdanovic, Z. (2005). Manifestation of kyphotic and lordotic bad body posture influenced by backpack carrying type. In S. Joksimovic (Ed.), Proceedings of "Fis-communications 2005" (pp. 59 - 65). Nis: Faculty of Physical Education.

Milenkovic, S. (2001). The influence of programmed corrective gymnastics exercising on the postural status of pupils engaged in tennis school training process. Unpublished master thesis. Nis: Faculty of Physical Education.

Zivkovic, D. (1987). The influence of programmed physical education curriculum on the spinal column deformities in frontal plane. Unpublished doctoral dissertation. Nis: Faculty of Philosophy, Physical Education Department.

Zivkovic, D. (2000). Theory and methodics of corrective gymnastics. Nis : SIA.

Zivkovic, D. \& Milenkovic, S. (1993). Postural deformities in pre-school children. In N. Zivanovic (Ed.), Proceedings of "Fis-communications '95" (pp. 159 - 160). Nis : Faculty of Philosophy, Physical Education Department.

\section{BA Purenovic Tijana}

Postgraduate student of Faculty of Sport and Physical Education, University of Nis

Home address: Bul dr Zorana Djindjica, 23/24

18000 Nis, Serbia

Phone numbers: +381 18 228066; +381 64

1453462

e-mail: tijana_purenovic@yahoo.co.uk 